\title{
ANALYSIS OF INFLUENCING FACTORS THAT CAN CAUSE ERRORS IN THE APPLICATION OF MODERN METHODS OF SLIDING BEARING DIAGNOSTICS IN MACHINE AND ELECTRICAL SYSTEMS
}

\author{
Nikola P. Žegarac \\ Serbian Academy of Inventors and Scientists, \\ Belgrade, Republic of Serbia, \\ e-mail: zegaracnikola@vektor.net, \\ ORCID iD: (i)https://orcid.org/0000-0002-1766-8184
}

DOI: 10.5937/vojtehg68-27265; https://doi.org/10.5937/vojtehg68-27265

\begin{abstract}
FIELD: Mechanical engineering, Energetics, Shipbuilding ARTICLE TYPE: Original scientific paper
\end{abstract}

\begin{abstract}
:
Introduction/purpose: The paper presents the application of modern methods in the diagnostics of sliding bearings and the analysis of influencing factors that can cause errors in such an application. Possibilities to determine with certainty when and where problems affect sliding bearings during system operation are presented. It is also shown how the system will continue to function over time. Causes of failures and the manner of their elimination are predicted, as well as the time for planned maintenance of technical systems.

Method: The new method solves the problem of sliding bearing diagnostics by measuring the dynamic trajectories of the sleeve in the sliding bearing and by measuring vibration parameters on the inner and outer surfaces of the technical system. The dynamic trajectories of the bearing sleeve are measured with non-contact probes; therefore, the centering of probes in relation to the geometric center of the bearing is very important. Vibration parameters, directly related to the clearance in the sliding bearing, are measured on the inner and outer surfaces of the system. The choice of vibration parameters and measuring points is very important. This method has a number of advantages over other diagnostic methods, as it is easy to access measuring points.
\end{abstract}

ACKNOWLEDGEMENT: The author would like to express his sincere gratitude to worldrenowned scientists and experts from many institutes and laboratories, in Serbia and abroad, for their successful and long-term collaboration. The author is especially grateful to General Branko Bilbija, a test pilot, who has flown on most modern military aircraft in many countries. With his considerable knowledge and experience of science and technology, he was of valuable support to the author's scientific and research work. 
Results: By measuring the dynamic trajectory of the sleeves in the plain bearing and vibration parameters on the inner and outer surfaces, the bearing clearance quantities are determined, including: normal condition, initial clearance size, its further increase, bearing clearance sizes, and the moment when the condition parameters are close to the upper limit of the permissible bearing clearance.

Conclusion: New diagnostic methods and monitoring systems can be widely applied to: internal combustion engines, all piston machines, hydroelectric power plants, thermal power plants, processing plants, and many other systems.

Keywords: technical diagnostics, sliding bearing, bearing clearance, bearing wear, bearing sleeve, dynamic trajectory.

\section{Introduction}

Modern methods of technical diagnostics enable fast and reliable measurement of the size of clearance (bearing wear) in sliding bearings, measurement of vibration parameters, vibration analysis, measurement of speed, measurement of lubricating oil temperature, lubricating oil analysis, measuring coolant temperature, positioning the top dead center in the case of internal combustion engines, etc. Since these are multichannel measuring systems, a large number of diagnostic parameters can be monitored and measured.

Based on the measured quantities, diagnostics of the condition of mechanical and electrical systems is performed. Data are obtained on the degree of wear and damage of machine elements (gears, shaft sleeves and shafts, sliding and roller bearings) as well as on imbalance which is very important for balancing the system in accordance with the prescribed standards. The selected failure symptoms mark relevant frequency components and create failure symptom sizes whose trend can be monitored. Alarm conditions can also be based on statistical estimates of the selected parameters.

During production, there are deviations from the manufacturing tolerances prescribed by the technical documentation due to various influences and installation errors. During operation, certain operating characteristics deviate more and more from the initial values so that proper operation is disrupted and the system working capacity is reduced. Therefore, it is very useful to pay special attention to these problems and do some research.

In recent years, there has been a significant increase in the share of diagnostics in the maintenance process, which is associated with safer operation, durability, reduced work, and maintenance costs. 
According to some research (Miroshnikov, LV, \& et al. 1977), (Genkin, MD, \& Sokolova AG, 1987), (Vasil'ev, Yu.N., \& et al. 1987), diagnostic works account for over $35 \%$ of the scope of technical maintenance work.

The largest number of papers in the field of technical diagnostics has been published in the Russian Federation, the USA and Japan, regardless of whether it is a vibration method or some other diagnostic method. In the professional literature of Western countries, specific studies are rarely given, although it is well known that a large number of manufacturers of internal combustion engines allocate huge financial resources for the development and research of engines. The basic principles (Cohn et al, 1975), (Zhdanovsky, NS 1966), (Thomson, 1983), (Fertis, 1973), (Schiffbänker \& Gerhard, 1988) are usually presented so that data on the results and possibilities of application of technical diagnostics for engines are very scarce.

Since technical diagnostics needs increasing financial and other costs, expensive measuring equipment and automation, it is necessary to pay attention to the convenience for modern control and monitoring requirements in system development and design.

Increasing control convenience for which there must be evaluation indicators leads to a reduction in the diagnostic work scope, which means that it is necessary to ensure and improve the availability of diagnostics, comfort, ease and accuracy of measurement, unification of control points, number of control points, measuring equipment, diagnostic methods, continuous registration of measured values and collection of information on the technical condition of systems.

The technical condition of a plant is characterized by a large number of operating process parameters. At the same time, not all parameters of the operating process affect the state of the system equally. Therefore, it is necessary to take as many parameters as possible during control in order to more completely determine the condition of the plant. When choosing the diagnostic parameters of the plant, it is necessary to determine the character of their relation with the parameters of the technical condition. In order for the output process parameter to be applicable in technical diagnostics, it must meet certain requirements:

- uniformity,

- width of the field of application, and

- availability of parameter measurement.

Damage to plain bearings in operating conditions can be classified into the following groups: 
- damage caused by material fatigue,

- damage due to increased bearing wear,

- damage caused by changing the size of the clearance between the sleeve and the plain bearing, and

- damage due to lack or interruption of the supply of bearing lubricating oil.

There are two concepts of monitoring systems in technical diagnostics:

The ON-line monitoring system intended for continuous measurement and analysis of technical conditions. Measuring sensors and systems are permanently installed on machine and electrical plants.

The OFF-line monitoring system intended for periodic measurements and analyses of technical conditions of plants. Some sensors are permanently built into the system (depending on which parameters are measured), and other sensors are placed together with the portable part of the monitoring system when measurements are to be performed.

\section{Sliding bearing dynamics and vibration generation}

Clearance in plain bearings occurs as an important indicator of the technical condition. It enables the assessment of significant movement of the sleeve when measuring dynamic trajectory and vibrations on the bearing housing. Related to this are the bearing structural parameters which include the shape, dimensions, clearances, material properties and other properties that characterize normal operation. The bearing-sleeve system must meet certain criteria so that the structural parameters of the assembly as a whole are within the prescribed limits, which determines the possibility of using the assembly.

Operation of a system with increased working clearance in the bearing causes a violation of lubrication conditions and increases the coefficient of friction, which is ultimately associated with damage to the bearing. Therefore, bearing wear is one of the basic parameters for diagnosing the technical condition. It is almost impossible to determine the laws of wear and tear exactly. It is possible to predict only one part of the type of wear based on the load forces on the sleeve and the sliding bearing.

The main types of wear observed during the system operation are adhesive and abrasive wear, material surface fatigue, and, to a lesser extent, wear due to erosion, fretting and corrosion. Normal wear and tear 
occurs due to the damage caused by tribological processes, as inevitable companions of the work of sliding bearings, while extremely intensive material surface wear occurs in extreme cases. Complete elimination of damage due to wear is impossible. Researching relevant parameters and offering a constructive solution ensure the smallest possible impact of unknown quantities and reduce damage due to the wear process to the smallest possible extent, thus increasing the reliability and durability of bearings. An important constructional dimension when designing a bearing is bearing clearance.

The absolute clearance (diametrical bearing clearance) is denoted as the difference between the bearing diameter $(D)$ and the sleeve diameter $(d)$ :

$$
Z_{D}=D-d
$$

The radial bearing clearance is defined as the difference between the bearing radius $(R)$ and the sleeve radius $(r)$ :

$$
Z=R-r
$$

The relative bearing clearance $(\psi)$ is the ratio of the clearance $\left(Z_{D}\right)$ to the sleeve radius unit $(d)$ :

$$
\psi=\frac{Z_{D}}{d}=\frac{D-d}{d}=\frac{R-r}{r}=\frac{Z}{r}
$$

Small bearing clearances increase the thickness of the oil film, while too small clearance values reduce oil flow, increase temperature and significantly reduce oil viscosity, leading to mixed friction which causes the oil to overheat and ultimately damage the bearing.

Increased clearances reduce energy losses and contribute to lower oil temperatures, and in local bearing locations where the maximum hydrodynamic pressures are in the oil film, there is also an increase in bearing temperature. Figure 1 shows the influence of the relative clearance $(\psi)$ on the minimum oil film thickness $\left(h_{0}\right)$ for various oil inlet temperatures $(v)$.

The optimal values of the minimum oil film thickness are in the range $\psi=(0,7-1,2) 0 / 00$, which means that during the operation time the 
values of the oil film thickness in the bearing will decrease, although the bearing construction was performed optimally at the very beginning.

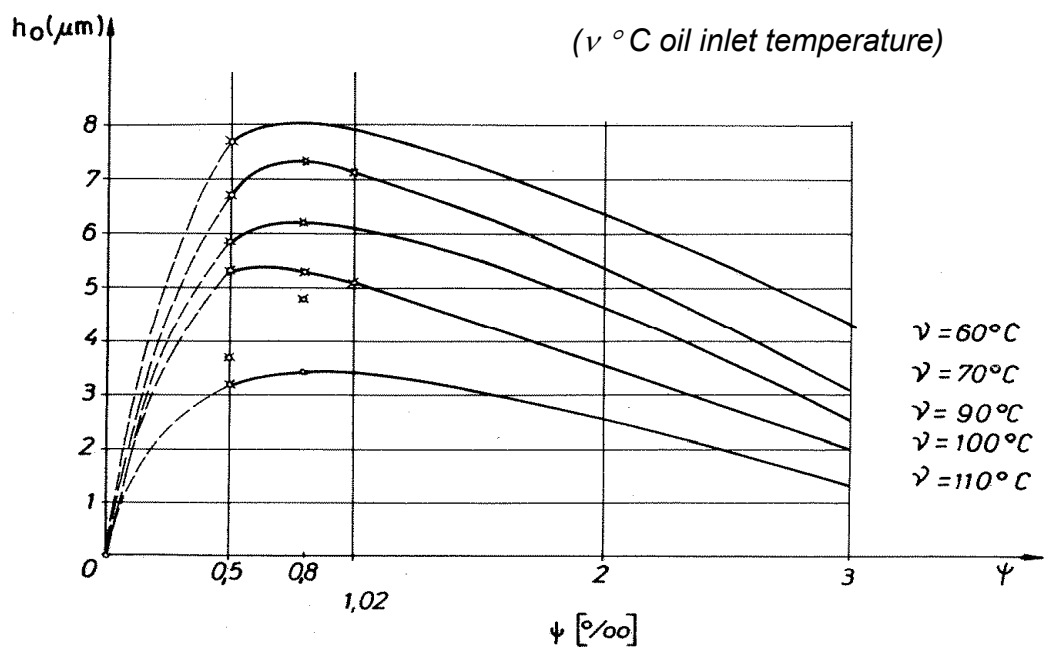

Figure 1 - Minimum thicknesses of the oil film depending on the relative clearance of the bearing

Рисунок 1 - Минимальная толщина масляной пленки в зависимости от относительного зазора подшипника

Слика 1 - Минималне дебљине уљног фрилма у зависности од релативног зазора лежаја

The parameters that define the vibration process in a plain bearing are: amplitude, phase shift, frequency, attenuation, etc. These parameters can show the wear of the sliding bearing which causes vibrational processes that increase or change when a defect occurs.

During working processes in mechanical and electrical plants, there are variable excitation forces, deformations, variable temperatures, different oil film thicknesses, different stiffness and damping. Consequently, different energies and vibration intensities will occur.

In the case of plain bearings, the reduction of vibration energy is influenced by friction forces. The coefficients of friction change values with the change of the oil temperature in the bearing. The coefficients of friction are significantly influenced by the lubrication conditions and the speed of rotation of the sleeve in the bearing. In real working conditions, damping is nonlinear so that the whole problem of a damping analysis becomes more complicated. 
Complex diagnostic objects, such as internal combustion engines, should be evaluated with a large number of structural parameters that change over time and cause system failures. One of the important components in the structure of the vibration signal is its intensity which can be expressed through three quantities: displacement, velocity, and acceleration. Displacement as a vibration parameter is suitable for investigating the complex movement of the bearing sleeve during normal wear, all the way to complete wear when the bearing must be replaced. For measuring points that are further away from the vibration source (bearing - sleeve), speed and acceleration can be used as parameters for describing vibrations.

Vibrations generated in coupled parts cannot be described by exact mathematical models (Fertis, 1973), (Schiffbänker \& Gerhard, 1988), (Zhdanovsky et al, 1977). These are non-periodic vibrations in which the rms values of the vibration parameters change by transmission through the system. Vibration signals are modulated. An overview of such changes is given in Figure 2.
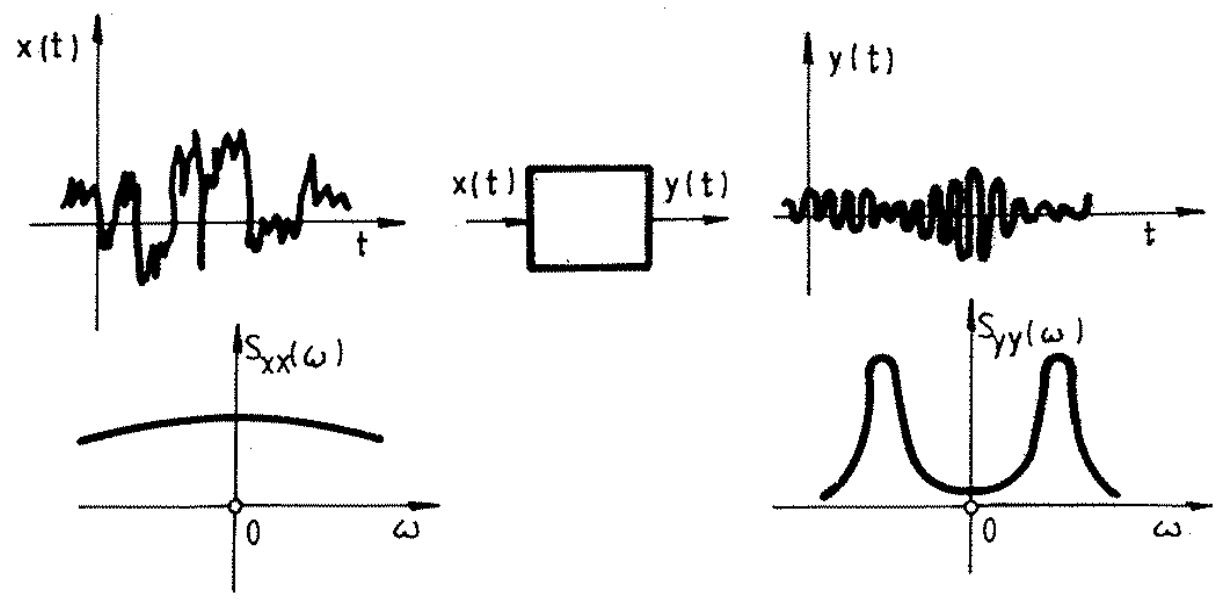

Figure 2 - Changes in the input signal through the system with the corresponding spectra Рисунок 2 - Изменения во входном сигнале через систему с соответствующими спектрами

Слика 2 - Промене улазног сигнала кроз систем са одговарајућим спектрима 


\section{Theoretical settings, calculation of sliding bearing diagnostic parameters and analysis of influencing factors that can cause certain errors in the application of diagnostic methods}

In order to examine the influence of the clearance on the dynamics of the sliding bearing, it is necessary to develop a theoretical model of the movement of the sleeve in the bearing with all the influencing factors. The theoretical model of sleeve movement is also a diagnostic model that will contain important settings for diagnostics.

When mathematically describing the theoretical model of backlash movement, it is necessary to give a connection between structural and diagnostic parameters, which represents a scientific contribution in this area.

The theoretical foundations of the calculation of a nonstationarily loaded sliding bearing are described by the Reynolds differential equation (Lang \& Steinhilper, 1978). The equation describes the pressure distribution in the direction of bearing volume and width. Considering the problem of lubrication of plain bearings, Reynolds started from several assumptions that greatly simplify the equation:

- along the entire cross section of the bearing there is no change in the viscosity of the observed fluid,

- the observed fluid is an incompressible liquid,

- external forces acting on the fluid can be neglected because they are very small in relation to the tangential forces acting in the fluid layers,

- the fluid flow in the bearing is laminar, the flow rate is constant,

- the curvature of the sliding surfaces can be neglected, since the dimensions of the body between which the oil film is formed are significantly larger compared to the dimensions of the oil film, so that instead of rotation there is a plane motion, and

- the weight and inertia of the fluid are neglected.

These simplifications of the Reynolds equation allow the calculation of the nonstationary force loading the bearing. This force contains the component due to rotation $\left(F_{0}\right)$ and the component due to pressing the sleeve $\left(F_{P}\right)$ in the bearing, (Figure 3 ). 


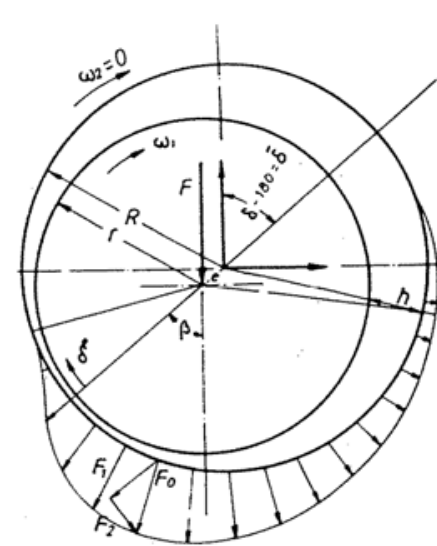

a) rotation

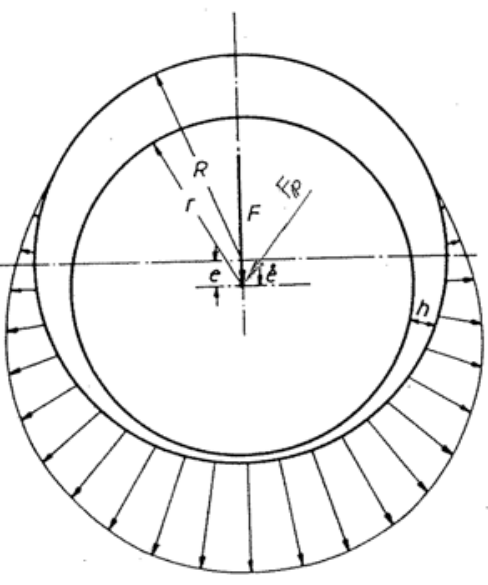

b) pressure

Figure 3 - Display of a radial bearing with dynamic load forces Рисунок 3 - Отображение радиального подшипника с динамическими нагрузками Слика 3 - Приказ радијалног лежаја са динамичким силама оптерећења

This paper presents internal combustion engines as complex diagnostic objects. A special problem is the procedure for determining dynamic forces acting on plain bearings in multy-cylinder engines. For theoretical and experimental research, an in-line marine diesel fourstroke 6-cylinder engine type 6ASL-25D, manufactured by JUGOTURBINA - SULZER, was used.

In the scientific research work, the diagnostics of the main bearings of the engine crankshaft was considered. The load on the sliding bearings of the engine crankshaft is caused by the action of combustion forces and inertial forces. Inertial forces arise from rotating and oscillating masses. In this paper, a detailed analysis of the action of all forces on the engine piston mechanism and on the crankshaft as a whole was performed in a completely new way. Previous calculations have been made on the basis of approximations of quantities, for example that $1 / 3$ of the mass of the connecting rod is in a rectilinear motion and $2 / 3$ of the mass is in a circular motion. It was also not taken into account that the connecting rod makes a complex movement during engine operation. Based on the new procedure for calculating the piston mechanism, kinetostatic and dynamic models were developed and used to determine all kinematic and dynamic quantities (Žegarac, 1989). The deformations of the bearing housing were not taken into account in the calculation, which later turned out to have no special effect. 
The calculation of the dynamic parameters was performed for different values of radial clearances in the main bearings: a clearance size of $Z=84 \mu \mathrm{m}$ when a new clearance bearing was installed in the engine, a clearance size of $Z=124 \mu \mathrm{m}$ when the engine was running half of the working resource, and a clearance size of $Z=144 \mu \mathrm{m}$ when the engine ran for the entire working life and the bearing had to be changed.

The time-varying dynamic trajectory of the main sleeve is caused by dynamic non-stationary load. The first computational dynamic model for plain bearings was developed by scientists (Lang \& Steinhilper, 1978). Significant improvements have been made according to (Žegarac, 1989).

The method of calculating the dynamic parameters used for the diagnosis of sliding bearings is based on the balance of the external force $(F)$ and the hydrodynamic forces due to the rotation of the sleeve $\left(F_{0}\right)$ and the pressing of the sleeve $\left(F_{P}\right)$. Based on the results of the calculation of dynamic quantities, it was shown that the 5 th foundation bearing, located between the 4th and 5th cylinder, is the most loaded on this engine. Figure 4 shows the polar load diagram of that bearing, when the value of the radial clearance is $Z=84 \mu \mathrm{m}$.

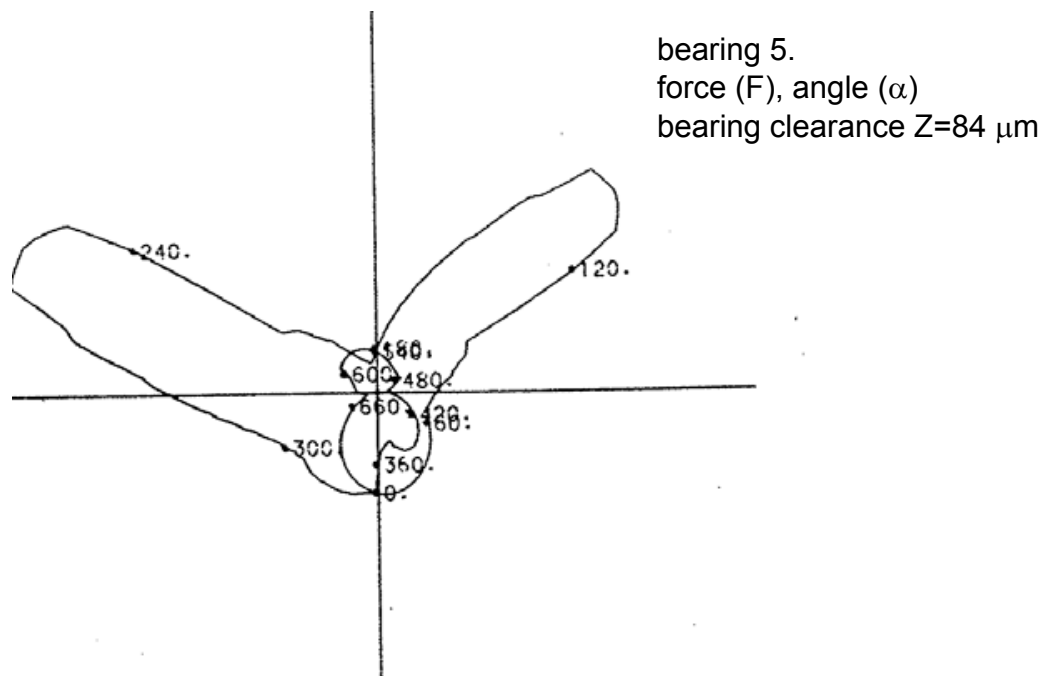

Figure 4 - Polar load diagram of the main sleeve of the 5th bearing depending on the angle of rotation of the engine crankshaft, bearing clearance $Z=84 \mu \mathrm{m}$ Рисунок 4 - Схема полярной нагрузки главной втулки 5-го подшипника в зависимости от угла поворота коленчатого вала двигателя, зазора в подшипнике $Z=84 \mu \mathrm{m}$

Слика 4 - Поларни дијаграм оптерећења главног рикавца 5. лежаја зависоно од угла заокрета коленастог вратила мотора, зазор лежаја Z $=84 \mu \mathrm{m}$ 
In Figure 5, a graphical representation of the dynamic force $(F)$ loading the bearing is given. Two dynamic pulses originating from the 4th and the 5th cylinder of the engine can be observed.

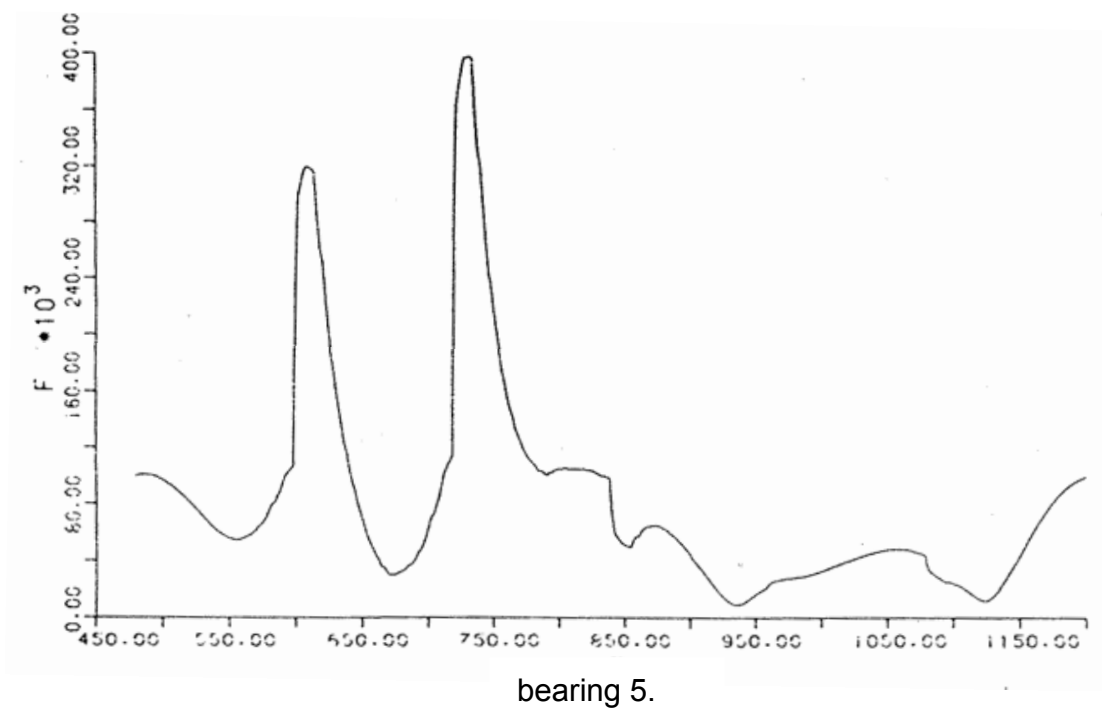

Figure 5-Change of the angle $((\gamma)$ and the load intensity of the main sleeve of the 5th bearing depending on the angle of rotation of the engine crankshaft Рисунок 5 - Изменение угла (( $\gamma)$ и интенсивности нагрузки главного рычага 5-го подшипника в зависимости от угла поворота коленчатого вала двигателя

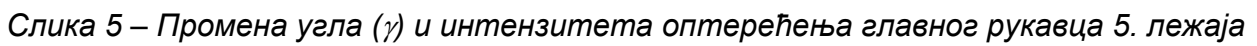
зависно од угла заокрета коленастог вратила мотора

Figure 6 shows the dynamic trajectory of the main bearing of the 5 th bearing, on which the parameters of the dynamic trajectory are most pronounced, since it is the most loaded bearing.

The value of the radial clearance is $Z=144 \mu \mathrm{m}$. 


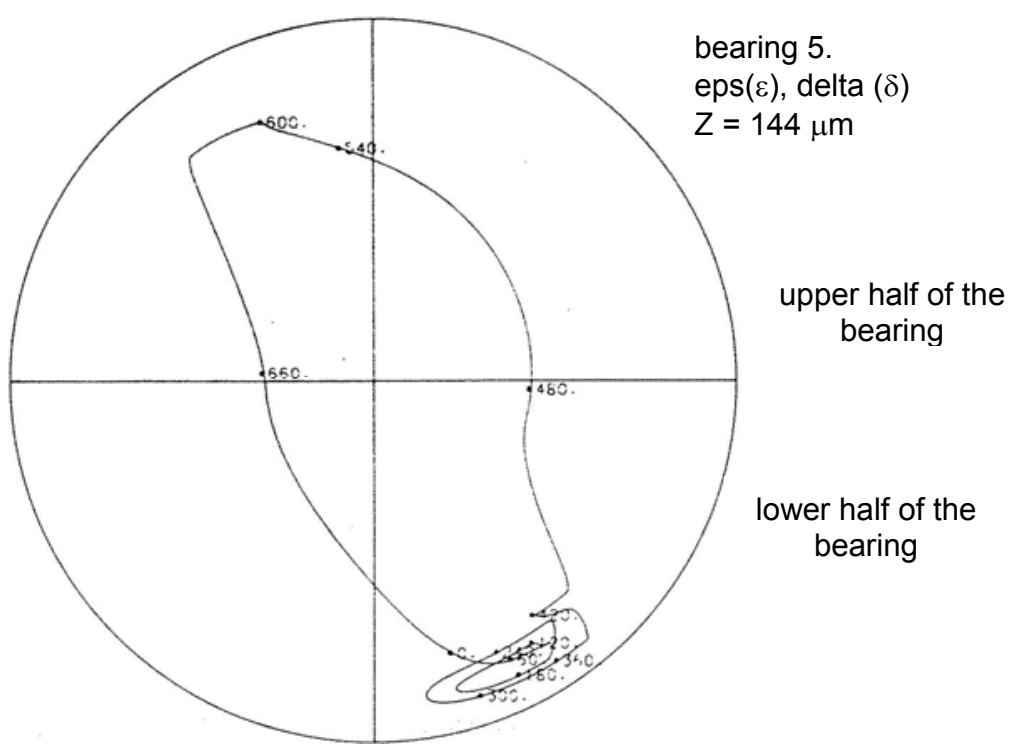

Figure 6-Dynamic trajectory of the main sleeve of the 5th bearing, the radius of the radial clearance $Z=144 \mu \mathrm{m}$

Рисунок 6 - Динамическая траектория главной втулки 5-го подшипника, значение радиального зазора $Z=144 \mu \mathrm{m}$

Слика 6 - Динамичка путања главног рукавца 5.лежаја, вердност радијалног зазора $Z=144 \mu \mathrm{m}$

Figure 7 shows the parameters of the dynamic trajectory of the main sleeve of the 5th bearing, the value of the eccentricity (e) for various bearing wear values $(Z=84 \mu \mathrm{m}, Z=124 \mu \mathrm{m}, Z=144 \mu \mathrm{m})$ depending on the crankshaft rotation time. The displayed (e) values differ significantly depending on the bearing wear. The crankshaft rotation angles $\left(\alpha=0^{\circ}-720^{\circ}\right)$ are marked on the dynamic trajectory.

The eccentricity of the sleeve (e), measured in $(\mu \mathrm{m})$, represents the distance of the center of the sleeve in relation to the geometric center of the bearing. The rotation time is measured in (ms). The eccentricity of the sleeve (e) and the parameter $(\delta)$, which represents the angle of the smallest thickness of the oil film $\left(h_{0 \min }\right)$, are the basic parameters for the bearing wear diagnostics. 

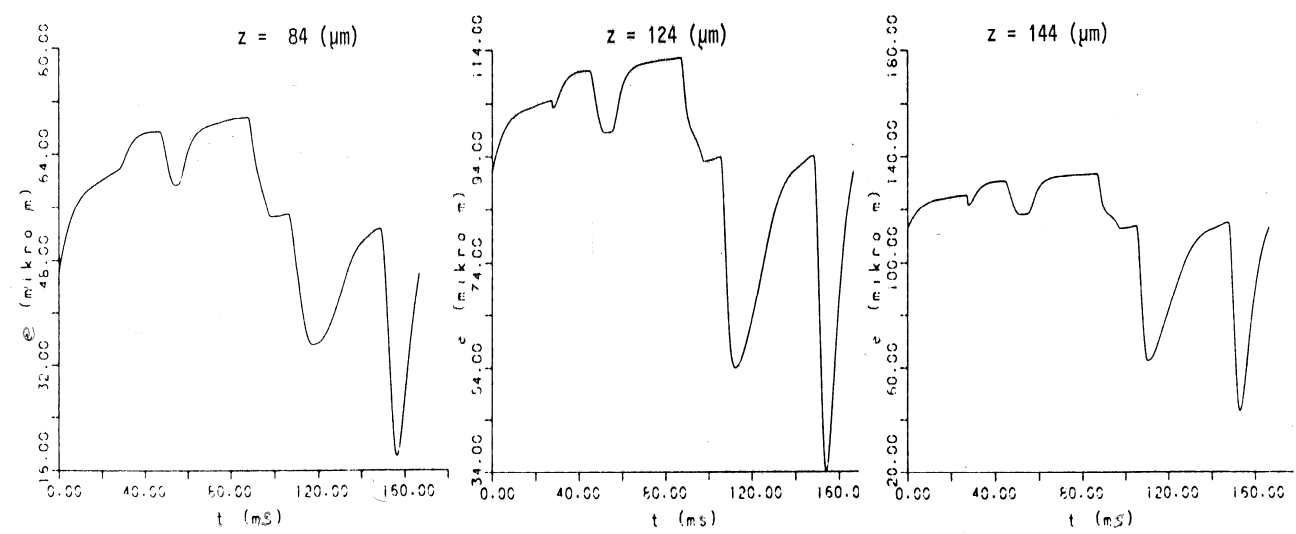

Figure 7 - Changing the eccentricity of the main bearing of the 5 th bearing for various bearing wear values, depending on the rotation time of the engine crankshaft Рисунок 7 - Изменение эксцентриситета основного подшипника 5-го подшипника при различном износе подшипника в зависимости от времени вращения коленчатого вала двигателя

Слика 7 - Промена ексцентрицитета главног рукавца 5. лежаја при разним истрошењима лежаја, зависно од времена ротације коленастог вратила мотора

\section{Experimental research and the analysis of diagnostic parameters of plain bearings}

The experimental research and the analysis of the diagnostic parameters related to the wear of plain bearings were performed on a marine diesel engine type 6ASL-25D, manufactured by SULZER JUGOTURBINA - Karlovac.

The engine is in-line, 6-cylinder, four-stroke, turbocharged and water-cooled. The rated motor power at speed $n=720 \mathrm{~min}^{-1}$ is $P e=927 \mathrm{~kW}$.

In the research program, the influence of the clearance of the main sliding foundation bearings of the engine crankshaft was examined. On the same motor, 3 sets of bearings with radial clearance values of $Z=84 \mu \mathrm{m}, Z=124 \mu \mathrm{m}$, and $Z=144 \mu \mathrm{m}$ were replaced in order to determine exclusively the influence of clearance on dynamic parameters and vibrations on the internal and external surfaces of the engine.

The test program was prepared in detail, setting out the general requirements that had to be met before and during research:

- before the start of the diesel engine, the hydraulic brake was calibrated in the engine test station, 
- the crankshaft sleeves of the engine must not have residual magnetism, since non-contact probes for measuring the displacement of the sleeve work on the inductive principle,

- the fuel supply system was set on the engine to have a more even supply of fuel in order to achieve a minimum difference in pressure on the engine cylinders, due to fuel combustion,

- compression pressure was measured in all engine cylinders,

- pressure measurement was performed at the end of the combustion process in all engine cylinders,

- all electronic measuring equipment was calibrated before and during the measurements and the analysis. For this purpose, the characteristics of the measuring equipment and the calibration factors were determined, which were taken into account during the measurement and the analysis, and

- during the measurement, the temperature of oil and water was constantly maintained. The data were entered into measurement protocols. In this way, other influences on the results of measuring diagnostic parameters were eliminated.

The measuring points on the engine were determined and the diagnostic parameters to be measured were defined, which can be seen from the illustration in Figure 8.

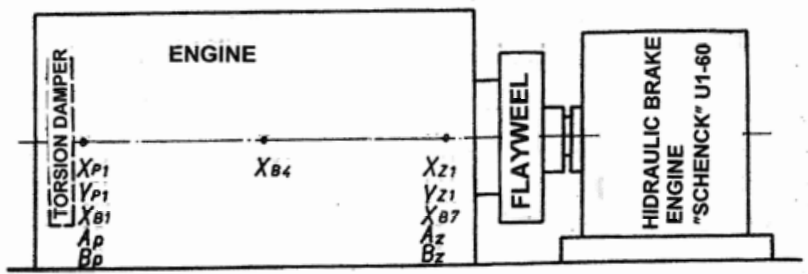

Xp1 - vibrations on the 1st main bearıng, norizontal aırecuon

Yp1 - vibrations on the 1st main bearing, vertical direction

$\mathrm{Xb} 1$ - vibrations on the side bolt of the 1st main bearing, horizontal direction

$\mathrm{Ap}, \mathrm{Bp}$ - displacement of the center of the sleeve of the 1st main bearing, direction of the probes $\mathrm{Ap}$ and $\mathrm{Bp}$

Xb4 - vibrations on the side screw of the 4th main bearing, horizontal direction

$\mathrm{Xz1}$ - vibrations on the 7th main bearing, horizontal direction

Yz1 - vibrations on the 7th main bearing, vertical direction

$\mathrm{Xb} 7$ - vibrations on the side bolt of the 7th main bearing

$\mathrm{Az}, \mathrm{Bz}$ - displacement of the center of the sleeve of the 7th main bearing, direction of the probes $\mathrm{Az}$ and $\mathrm{Bz}$

Figure 8 - Arrangement of the measuring points on the engine 6 ASL-25D Рисунок 8 - Расположение точек замера на двигателе 6 ASL-25D Слика 8 - Распоред мерних места на мотору 6 ASL-25D 
Figure 9 specifically shows the measuring points on the engine crankshaft on which the probes for measuring the dynamic trajectory of the sleeves on the 1st and 7th main bearings are placed. The dashed line on the cross section of the sleeve " $\mathrm{C}-\mathrm{C}$ " shows the deviation from the circular shape of the sleeve.
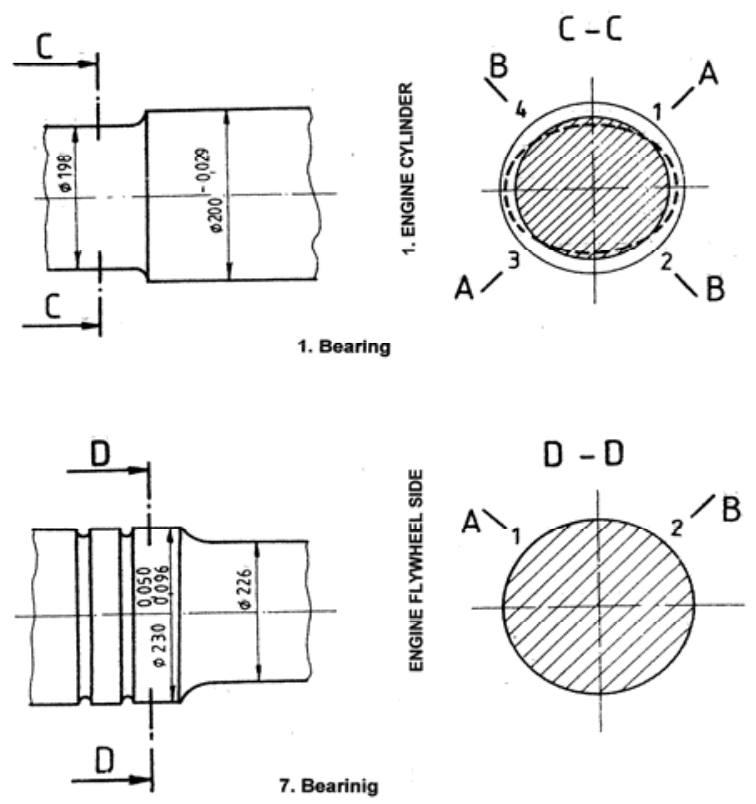

Figure 9 -Display of the measuring points with the positions of the probes for measuring the dynamic paths of the main sleeve

Рисунок 9 - Отображение точек измерения, где расположены датчики для измерения динамических траекторий главных рычагов

Слика 9 - Приказ мерних места на којима су постављене сонде за мерење динамичких путања главних рукаваца

The probes for measuring the dynamic trajectory are centered using a centering device (Žegarac, 1989), (Žegarac, 1993) or using an electronic centering device from the Swedish company Damalini (EasyLaser, 2020). Centering non-contact probes is very important for the measurement procedure and for obtaining accurate results.

Probes for measuring the temperature of all bearings are placed in the lower covers of the main bearings. An overview of the measuring points is given in Figure 10. 
The measuring device Hotinger Boldwin - Messtechnik UPM - 60 and thermometers PT-100 ATM - Zagreb were used for temperature measurement. The symbol (Tu) indicates the coolant temperature at the engine inlet and $\mathrm{(Ti}$ indicates the fluid temperature at the engine outlet.

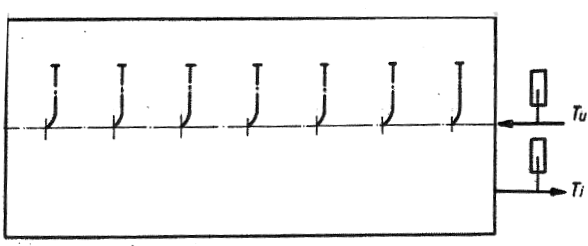

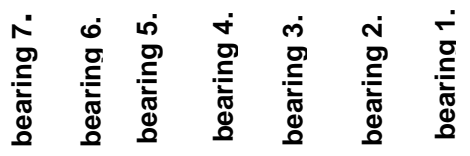

Figure 10-Overview of the measuring points where the temperature measurement of the main bearings of the engine crankshaft was performed

Рисунок 10 - Обзор точек измерения, где проводилось измерение температуры главных подшипников коленчатого вала двигателя

Слика 10 - Преглед мерних места на којима је извршено мерење температуре главних лежајева коленастог вратила мотора

Temperature was measured on the main bearings in all engine operating modes. In the no-load mode, at various speeds, the temperature values were in the range of $60-70{ }^{\circ} \mathrm{C}$, on almost all bearings. In the engine load mode of $20-110 \%$, the temperature values were from $65-80^{\circ} \mathrm{C}$.

The temperature values in this case were almost the same, even on the busiest 5 th main bearing.

The temperature change is shown in Figure 11. The temperature regime of the engine was under strict control, since the engine was tested at the maximum bearing clearance of $Z=144 \mu \mathrm{m}$. 


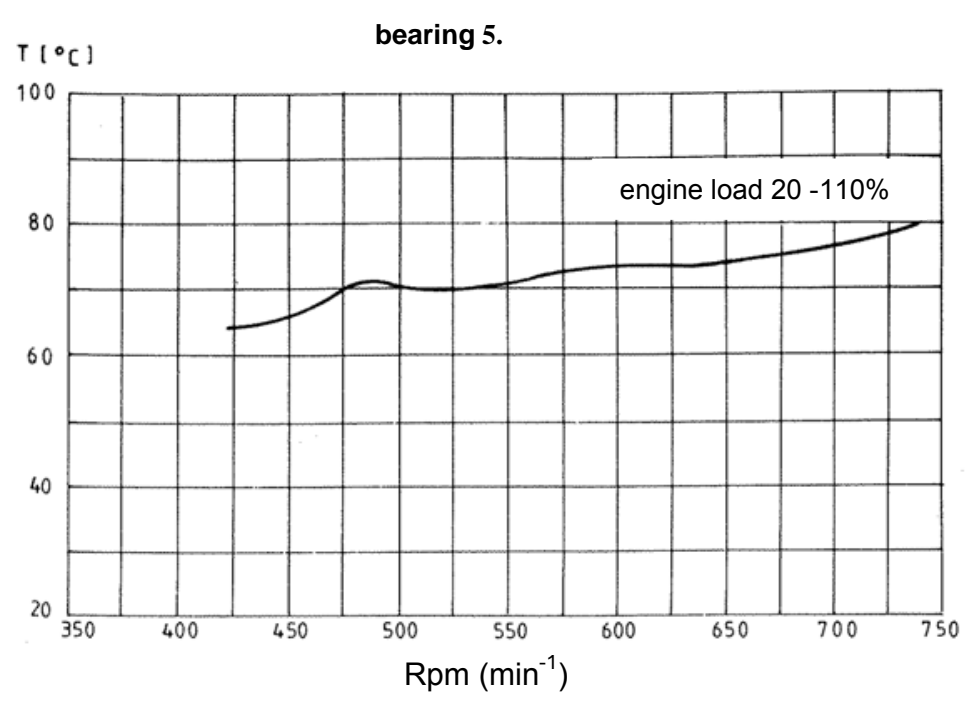

Figure 11 - Temperature change on the 5th main bearing depending on the engine load Рисунок 11 - Изменение температуры на 5-м главном подиипнике в зависимости от нагрузки двигателя

Слика 11 - Промена температуре на 5. главном лежају зависно од оптерећења мотора

Figure 12 shows a scheme for measuring the vibration characteristics of the engine.

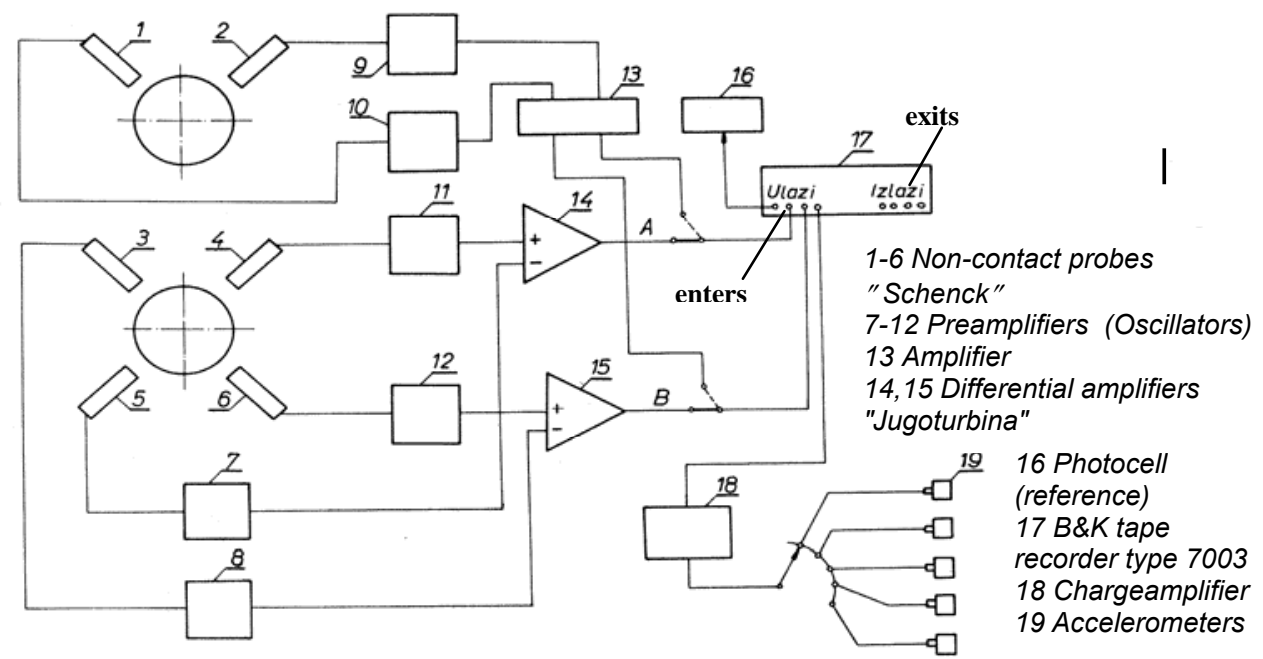

Figure 12 - Scheme of measuring the vibration characteristics of the engine $6 A S L-25 D$ Рисунок 12 - Схема измерения вибрационных характеристик двигателя 6ASL-25D Слика 12 - Шема мерења вибрацијских карактеристика мотора 6ASL -25D 
Figure 13 shows the non-contact probes of the German company "Schenck" for measuring the dynamic trajectory of the main sleeve bearing. The probes are of different sizes so that measurements can be carried out depending on the dimensions and the place where they are placed. They can be standard versions or with built-in oscillators.

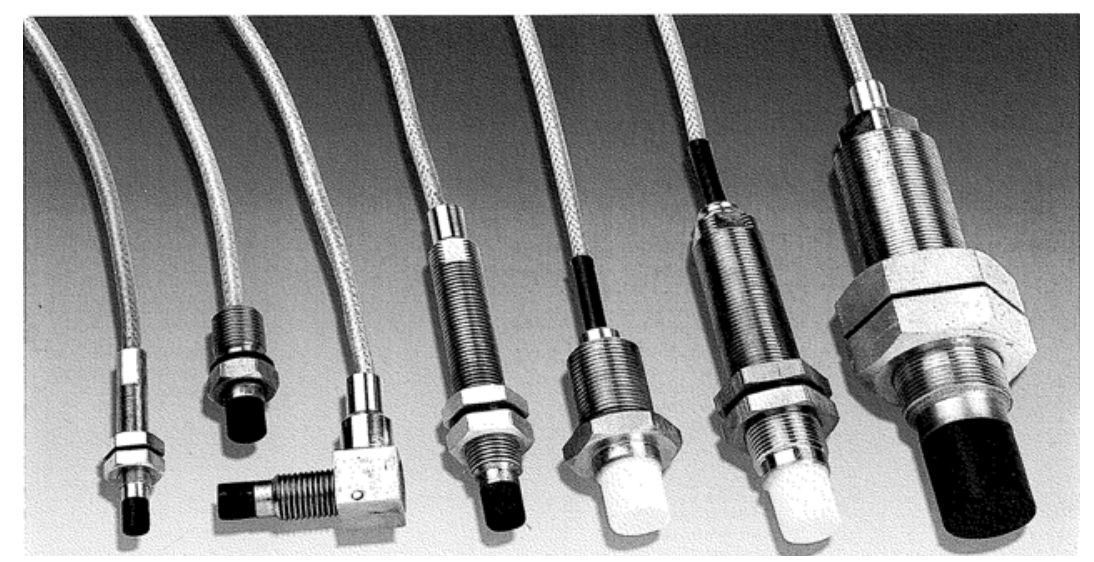

Figure 13 - Non-contact probes for measuring the dynamic paths of the main sleeve Рисунок 13 - Бесконтактные датчики для измерения динамических траекторий главных рычагов

Слика 13 - Бесконтактне сонде за мерење динамичких путања главних рукаваца

Starting from the theoretical bases, the defined methods of testing and the analysis, the engine tests provided by the program were carried out and the experimental research results were obtained.

In the first moment, no agreement was reached between the measured dynamic trajectory on the 1 st main bearing and the calculated trajectory. A detailed analysis was performed, based on which it was concluded that, when measuring and processing the signal, the irregularity of the circular shape of the sleeve, marked in Figure 9 with a dashed line at the cross section of the sleeve " $C-C$ ", should be taken into account.

This part of the sleeve is not intended to be machined more precisely during machining, as it is located outside the plain bearing.

The part of the sleeve that is inside the bearing is very precisely processed. Its deviation from the circular shape is $5 \mu \mathrm{m}$. 
The deviations from the circular shape of sleeve 1 of the main bearing are shown in Table 1, on the basis of which the results of the dynamic trajectory measurements were corrected.

Based on the results of the research, engine manufacturers could be recommended to precisely process these parts of the crankshaft, in order to simplify the procedure of diagnosing the engine.

More precise machining would not make the production process more expensive.

Table 1 - Deviations from the circular shape of the sleeve of the 1st main bearing of the engine crankshaft in $(\mathrm{mm})$

Таблица 1 - Отклонения от круглой формы втулки 1-го главного подшипника коленчатого вала двигателя в (мм)

Табела 1 - Одступања од кружног облика рукавца 1. главног лежаја коленастог вратила мотора у $(\mathrm{mm})$

\begin{tabular}{|c|c|c|c|}
\hline \multicolumn{4}{|c|}{ Nominal sleeve size $\varnothing 198$ mm } \\
\hline $\begin{array}{l}\text { Crankshaft rotation } \\
\text { angle }\left(\alpha^{\circ}\right)\end{array}$ & $\begin{array}{l}\text { Nominal } \\
\text { sleeve size }\end{array}$ & $\begin{array}{l}\text { Crankshaft rotation } \\
\text { angle }\left(\alpha^{\circ}\right)\end{array}$ & $\begin{array}{l}\text { Nominal sleeve } \\
\text { size }\end{array}$ \\
\hline $\left.0^{*}\right)$ & +0.001 & 190 & +0.012 \\
\hline 10 & +0.002 & 200 & +0.035 \\
\hline 20 & +0.003 & 210 & +0.039 \\
\hline 30 & +0.004 & 220 & +0.031 \\
\hline 40 & +0.004 & 230 & +0.031 \\
\hline 50 & +0.008 & 240 & +0.028 \\
\hline 60 & +0.013 & 250 & +0.026 \\
\hline 70 & +0.006 & 260 & +0.020 \\
\hline 80 & +0.024 & 270 & +0.018 \\
\hline 90 & +0.027 & 280 & +0.017 \\
\hline 100 & +0.036 & 290 & +0.011 \\
\hline 110 & +0.035 & 300 & +0.008 \\
\hline 120 & +0.015 & 310 & +0.003 \\
\hline 130 & +0.013 & 320 & 0.000 \\
\hline 140 & +0.035 & 330 & -0.002 \\
\hline 150 & +0.023 & 340 & -0.005 \\
\hline 160 & +0.012 & 350 & -0.007 \\
\hline 170 & +0.013 & 360 & -0.004 \\
\hline 180 & +0.033 & $\begin{array}{l}\left.{ }^{*}\right) \text { The piston of the } \\
\text { is located in the top } \\
\text { (TDC) }\end{array}$ & $\begin{array}{l}\text { linder of the engine } \\
\text { center }\end{array}$ \\
\hline
\end{tabular}


The results of the calculations and the measurements were not particularly affected by crankshaft deformations and additional inertial moments shown in Figure 13.
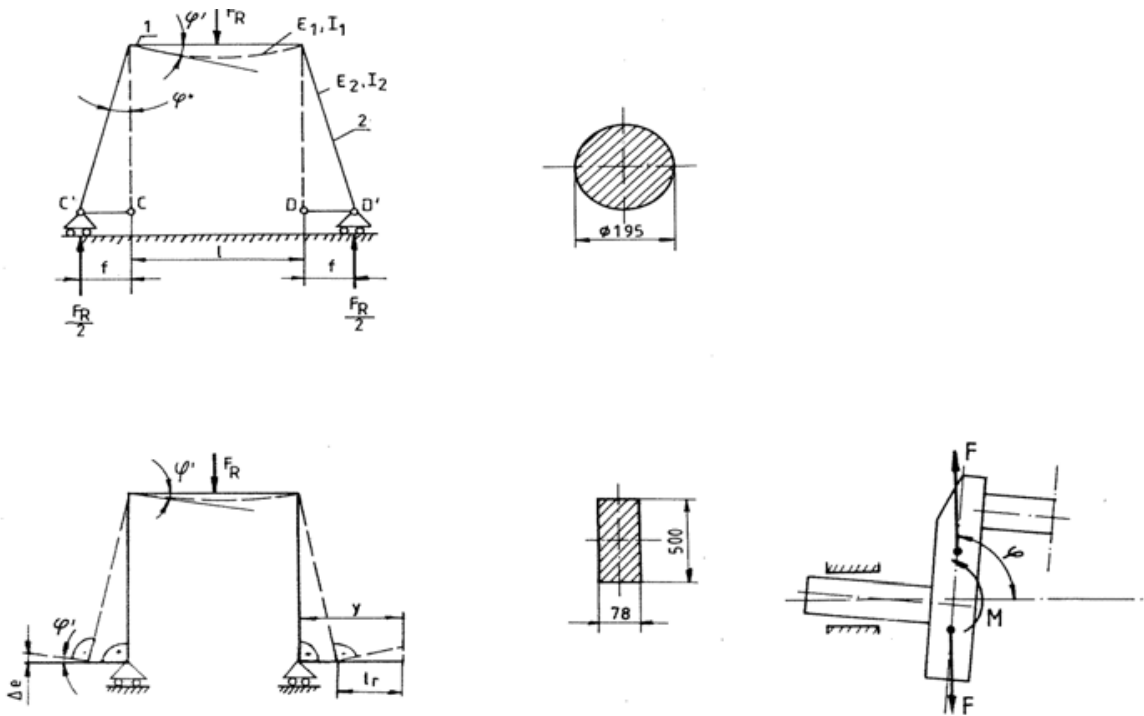

Figure 13-Deformations of the engine crankshaft and the influence of additional inertial moments

Рисунок 13 - Деформации коленчатого вала двигателя и влияние дополнительных инерционных моментов

Слика 13 - Деформације коленастог вратила мотора и утицај додатних инерционих момената

In Figure 14, the dynamic trajectory of the 1 st main bearing is shown

In the graphical display of the dynamic path, several engine operating cycles are shown.

The paths on the diagram are shown with several lines and the crankshaft rotation angle is indicated $\left(\alpha=0^{\circ}-720^{\circ}\right)$. It can be seen that there is very little difference in paths per engine cycle. 
The engine is well tuned, the engine speed is stable.

The agreement of the calculation and measurement results is in the range of $5 \%$.

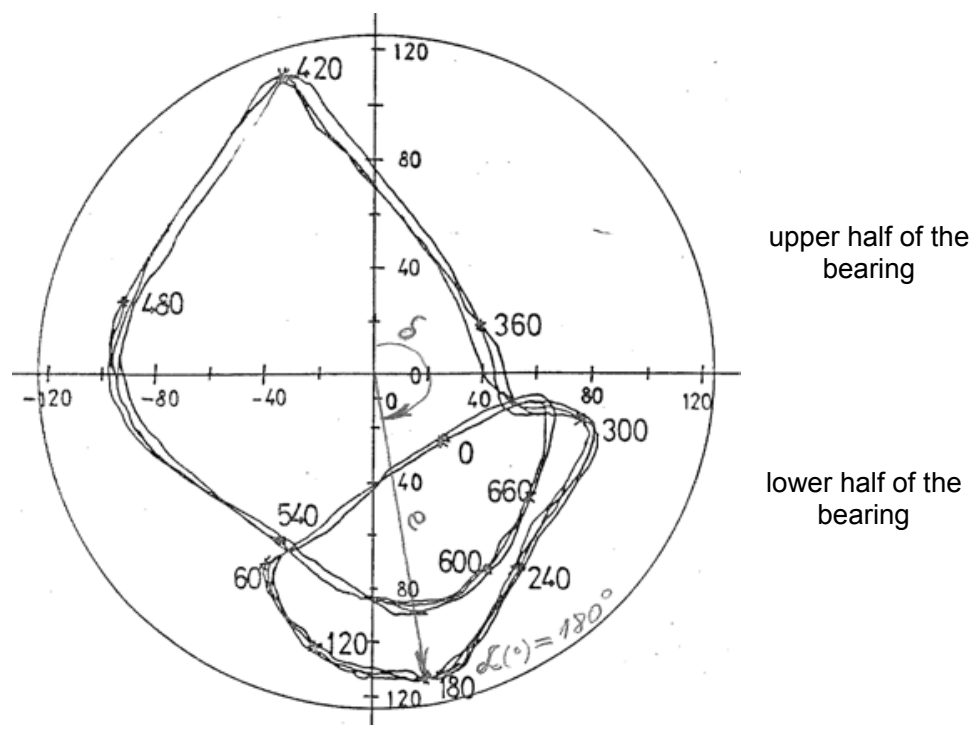

Figure 14 - Display of the measured dynamic sleeve trajectory on the 1st main bearing of the crankshaft, at the engine load of $100 \%$,

$n=720 \mathrm{~min}^{-1}$, and the bearing clearance $Z=124(\mu \mathrm{m})$

Puc. 14 - Изображение измеренной динамической траектории рукава в первом главном подшипнике двигателя коленчатого вала, при нагрузке на двигатель (100\%), $n=720$ мин $^{-1}$, зазор подшипника Z = $124(\mu \mathrm{m})$

Слика 14 - Приказ измерене динамичке путање рукавца на првом главном лежају мотора коленастог вратила мотора при оптерећењу мотора (100\%), $n=720$ $\min ^{-1}$, зазор лежаја $\mathrm{Z}=124(\mu \mathrm{m})$

Based on the measurement results, the dependence of the displacement of the center of the sleeve (e) and the clearance $(Z)$ was determined when driving the engine with and without load in the form (Žegarac, 2020):

$$
Z=1.01 \cdot e+7,48 \pm 4
$$

Previous research on the wear of vital parts of internal combustion engines has shown that crankshaft bearings wear evenly provided that all 
engine lubrication conditions are met (Žegarac, 1989). An indicator of bearing wear is sufficient, if diagnostic parameters are measured on any bearing.

Figure 15 shows the measured dynamic trajectory of the main sleeve on the 7th engine bearing. With increasing clearance, at different speeds and motor loads, differences in dynamic trajectory are observed, but there is no coincidence of the calculation and measurement results.

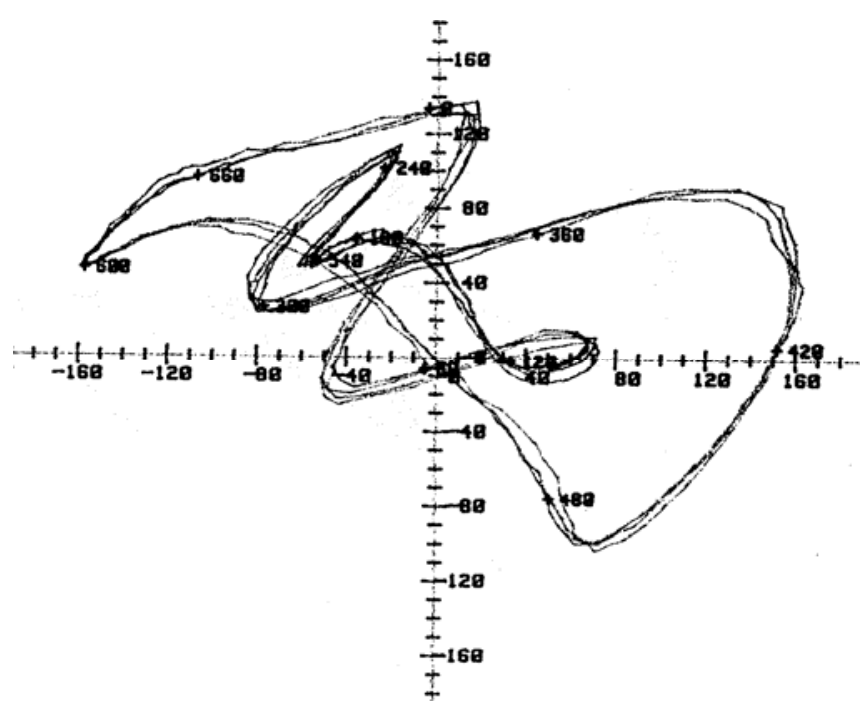

Figure 15 - Dynamic trajectory of the main sleeve on the seventh bearing of the engine crankshaft, engine load $100 \%$, bearing clearance $Z=144 \mu \mathrm{m}$, rotation speed

$$
n=720 \mathrm{~min}^{-1}
$$

Рисунок 15 - Динамическая траектория основного рычага на седьмом подшипнике коленчатого вала двигателя, нагрузка двигателя 100\%, зазор подшипника $Z=144 \mu$, частота вращения $n=720$ мин $^{-1}$

Слика 15 - Динамичка путања главног рукавца на седмом лежају коленастог вратила мотора, оптерећење мотора 100\%, зазор лежаја Z $=144 \mu \mathrm{m}$, брзина вртње $n=720 \mathrm{~min}^{-1}$

The dynamic trajectory was measured on the part of the sleeve located on the outside of the engine block. 
The shape of the dynamic trajectory was influenced by static and dynamic deformations of the crankshaft due to the weight of the engine flywheel.

The illustration is given in Figure 16. It would probably be possible to measure dynamic trajectories on this part of the engine crankshaft in multi-cylinder engines that do not have flywheels since such engines are dynamically balanced due to a larger number of engine cylinders.

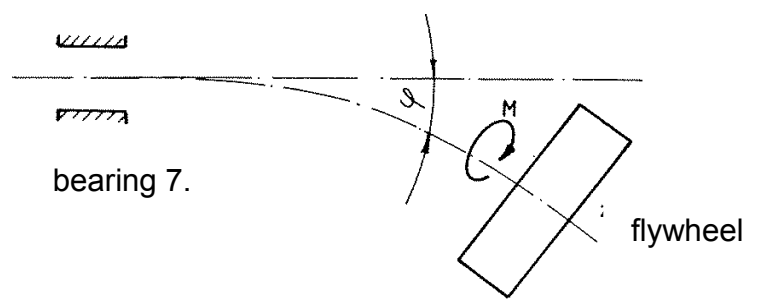

Figure 16 - Deformations of the main sleeve on the 7th bearing of the engine crankshaft

Рисунок 16 - Деформации главного рычага седьмого подшипника коленчатого вала двигателя

Слика 16 - Деформације главног рукавца на 7. лежају коленастог вратила мотора

The vibration parameters were measured at 7 measuring points, on the inner and outer surfaces of the engine (shown in Figure 8):

Xp1 - vibrations on the 1st main bearing, horizontal direction,

Yp1 - vibrations on the 1st main bearing, vertical direction,

$\mathrm{Xb} 1$ - vibrations on the side bolt of the 1st main bearing, horizontal direction,

Xb4 - vibrations on the side screw of the 4th main bearing, horizontal direction,

Xz1 - vibrations on the 7th main bearing, horizontal direction,

Yz1 - vibrations on the 7th main bearing, vertical direction, and

$\mathrm{Xb} 7$ - vibrations on the side bolt of the 7th main bearing.

Based on the results of measuring the vibration parameters, it was determined that the highest vibration levels are at measuring point 3 , (Figure 17), Xb1, horizontal direction, on the side screw that fastens the lower cover of the main bearing in the engine block. Figure 17 shows the 
effective values of the vibration velocity Vef $(\mathrm{mm} / \mathrm{s})$, harmonic of the $1 \mathrm{st}$ order, at different speeds and motor loads, when the bearing clearance is $Z=144 \mu \mathrm{m}$. It was concluded that the frequency components (harmonics) of 0.5 and 1 . order are most related to bearing wear. The harmonics of $1.5,2,2.5,3$ and 3.5 are less pronounced. The intensity of vibrations is related to the variable excitation forces from the bearing to the bearing in the horizontal and vertical planes of the engine. It was found that the higher level of vibration is in the horizontal plane of the engine, on the side of the 1st cylinder of the engine, which is significantly contributed by large weights of the parts located on the engine crankshaft - torsional vibration damper on the front of the engine whose weight is $\mathrm{Gp}=3558$ $(\mathrm{N})$ and the parts on the side of the 6th engine cylinder - the gear that drives the systems on the engine whose weight is $\mathrm{Gzu}=1176(\mathrm{~N})$ and the engine flywheel weight of $\mathrm{Gz}=7106(\mathrm{~N})$.

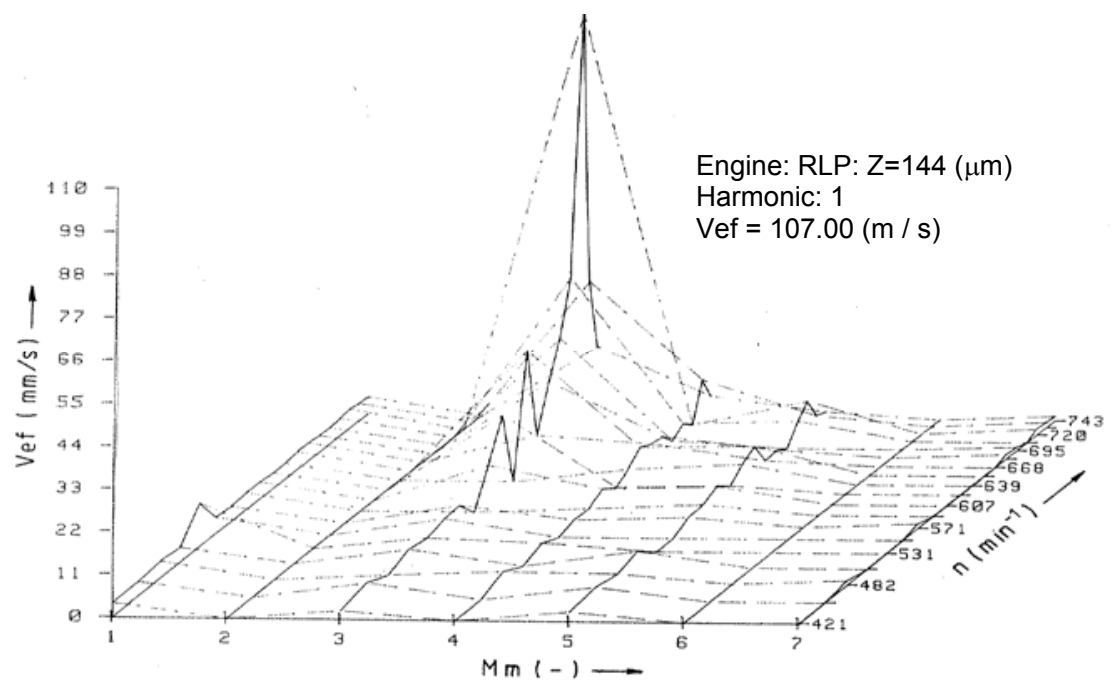

Figure 17 - Effective value of the vibration speed (Vef) for different measuring points at different speeds and motor loads

Рисунок 17 - Эфрфрективное значение скорости вибрации (Vef) для различных точек измерения при разных скоростях и нагрузках двигателя

Слика 17 - Ефективна вредност вибрацијске брзине (Vef) за разна мерна теста при различитим брзинама вртње и оптерћењу мотора

Many reputable companies deal with technical diagnostics of sliding bearings. Some well-known companies are Bently Nevada, Emerson 
Electric, Brüel \& Kjær and others, whose systems are installed on hydroelectric power plants, thermal power plants and other facilities.

In these systems, a problem is created by the roto group in the system: there is a mechanical, electrical and hydraulic imbalance of the rotor. Figure 18 shows a bearing housing on which non-contact probes for measuring dynamic paths of roto systems are mounted, according to the configuration of Bently Nevada (Bently Nevada Corporation, 1987).
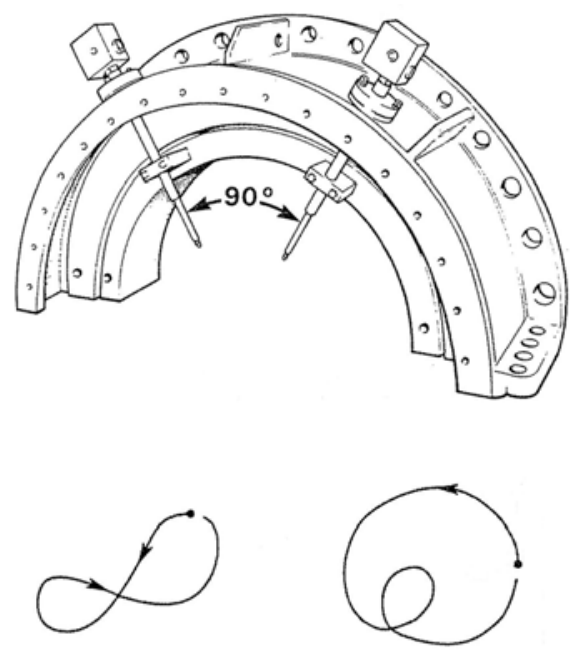

Figure 18 - View of the bearing cover showing the non-contact probes for measuring the dynamic path according to the configuration of the Bently Nevada company

Рисунок 18 -- Вид крышки подшипника, показывающий бесконтактные датчики для измерения динамического пути в соответствии с конфригурацией компании Bently Nevada

Слика 18 - Поглед на поклопац лежаја који приказује бесконтактне сонде за мерење динамичке путање по конфицурацији форме Bently Nevada

\section{Conclusion}

The reliability and durability of internal combustion engines and other engines is a function of correct operation and durability of individual parts, of which plain bearings are especially important. Besides being influenced by construction dimensions and types of lubricating oil, wear intensity of plain bearings is also affected by operating conditions and system maintenance. The mutual influences of the parameters describing 
the wear of plain bearings are very complex and cannot be reliably described mathematically. Therefore, simplified mathematical models, used to describe these phenomena, give approximate bearing wear functions.

With the development of the method of calculation of plain bearings, which determines the data on the function and construction parameters of bearings (oil film thickness, forces on the bearing), it was found out which bearing is the most loaded. At this measuring point, the dynamic parameters related to the increase of the clearance in the bearing are most pronounced, although in reality all bearings are worn evenly, if all the conditions for lubrication of plain bearings are met.

The original mathematical formulas that determine the dimensions of clearance in the bearing based on measurements are completely reliable. Lang's approximate formulas for non-stationary bearing loading were used.

Modeling dynamic models of internal combustion engines was used as an example to describe all engine dynamic parameters in a completely new way. Based on that, the results of the calculation and the measurements of the dynamic parameters were verified and the deviations were within the range of $5 \%$.

Experimental methods are the most authoritative for the final assessment of bearing wear. Based on the performed measurements of the dynamic trajectory of the sleeve and the vibration parameters on the inner and outer surfaces, the actual state is determined without disassembling assemblies and detailed inspections.

Measurement of the dynamic trajectories of the bearing sleeve is performed using non-contact probes. Measurements can be made with 1 contactless probe or with 2 and 4 of them. Contactless probes are installed on special supports which are fixed in the immediate vicinity of the measuring point. If access to the bearing is limited (due to small bearing dimensions), probes can be installed in the bearing housing.

It is especially important to measure the vibration parameters on the inner and outer surfaces of the engine that are directly related to the clearance in the sliding bearing. The choice of vibration parameters and measuring points is important. This method has a number of advantages over other diagnostic methods, as it is easy to access the measuring points.

A database related to the degree of bearing wear should be created for each diagnostic case. Engines differ significantly in construction, operating conditions and load. It is important to strictly adhere to the norms set by the system manufacturers regarding when plain bearings 
have to be changed, i.e. when bearing wear reaches the wear limit values.

In the final assessment of the technical condition, the vibration standards from the prescribed vibration standards (ISO, 1974, 1995) must be taken into account, due to the fact that drive systems are coupled with other assemblies in mechanical and electrical systems, which can interactively affect the operation of the whole system.

The spectral and correlation analysis of signals obtained on the basis of measuring vibration parameters on internal and external surfaces singles out frequency components related to wear of plain bearings, at different speeds and operating modes without load and with motor load. The diagnostic method does not require special preparations and auxiliary devices for the installation of the measuring system. Measurements are performed very simply and reliably. Repeatability of the measurement results was achieved.

The person performing the diagnosis must have top knowledge and experience in this field in order to qualitatively select diagnostic parameters and measuring points, assess the factors influencing the measurement results and analyze the measured quantities.

New diagnostic methods can determine bearing wear accurately enough. New diagnostic methods and monitoring systems have a wide range of possibilities of application: internal combustion engines, all piston machines, hydroelectric power plants, thermal power plants, process plants, and other plants. The new monitoring system for sliding bearing diagnostics offers hardware and software support to various systems for monitoring and checking the compatibility of devices and equipment of many manufacturers, which are used for plant technical diagnostics.

\section{References}

-Bently Nevada Corporation. 1987. Turbine Supervisory Instrumentation Brochure, L2016, february. Nevada, US: Bently Nevada Corporation.

Cohn-Sfetcu, S., Smith, M.R., Nichols, S.T. \& Henry, D.L. 1975. A digital technique for analyzing a class of multicomponent signals. Proceedings of the IEEE, 63(10), pp.1460-1467. Available at: https://doi.org/10.1109/PROC.1975.9975.

-Easy-Laser. 2020. Laser measurement \& alignment systems. Technical documentation. Damalini, Sweden: Easy-Laser. 
Fertis, D.G. 1973. Dynamics and Vibrations of Structures. New York: John Wiley \& Sons.

Genkin, M.D. \& Sokolova, A.G. 1987. Vibroakusticheskaya diagnostika mashin i mekhanizmov. Moscow: Mashinostroenie (in Russian). (In the original: Генкин, М.Д., Соколова А.Г. 1987. Виброакустическая диагностика машин и механизмов. Машиностроение: Москва).

-ISO. 1974. ISO 2372:1974 Mechanical vibration of machines with operating speeds from 10 to $200 \mathrm{rev} / \mathrm{s}$ - Basis for specifying evaluation standards [online]. Available at: https://www.iso.org/standard/7212.html [Accessed: 12 June 2020].

-ISO. 1995. ISO 10816-1:1995 Mechanical vibration - Evaluation of machine vibration by measurements on non-rotating parts - Part 1: General guidelines [online]. Available at: https://www.iso.org/standard/18866.html [Accessed: 12 June 2020].

Lang, O.R. \& Steinhilper, W. 1978. Gleitlager. Berlin, Heidelberg: SpringerVerlag (in German). Available at: https://doi.org/10.1007/978-3-642-81225-5.

Miroshnikov, L.V., Boldin, A.P. \& Pal, V.I. 1977. Diagnostirovaniye tekhnicheskogo sostoyaniya avtomobiley na avtotransportnykh predpriyatiyakh. Moscow: Tehnika (in Russian). (In the original: Мирошников, Л.В., Болдин, А.П., Пал В.И. 1977. Диагностирование технического состояния автомобилей на автотранспортных предприятиях. Москва: Транспорт).

Schiffbänker, H. \& Gerhard, E.T. 1988. Automatische Gutekontrole an Verbrennungsmotoren auf Basis von Schingungs Informationen. MTZ Motortechnische Zeitschrift, 49(2) (in German).

Thomson, W.T.1983. Theory of Vibration with Applications, Second edition. London: George Allen \& Unwin Ltd.

Vasilyev, Yu.N., Beskletnyy, M.Ye., Igumentsev, Ye.A. \& Khristenzen, V.L. 1987. Vibratsionnyy kontrol' tekhnicheskogo sostoyaniya gazoturbinnykh gazoperekachivayushchikh agregatov. Moscow: Nedra (in Russian). (In the original: Васильев, Ю.Н., Бесклетный, М.Е., Игуменцев, Е.А., Христензен, В.Л. 1987. Вибрационный контроль технического состояния газотурбинных газоперекачивающих агрегатов. Москва: Недра). 
Zhdanovskiy, N.S. 1966. Bestormoznyye ispytaniya traktornykh dvigateley. Moscow, Leningrad: Mashinostroenie (in Russian). (In the original: Ждановский, Н.C. 1966. Бестормозные испытания тракторных двигателей. Москва, Ленинград: Машиностроение).

Zhdanovskiy, N.S. 1977. Diagnostika avtotraktornykh dvigateley. Leningrad: Kolos (in Russian). (In the original: Ждановский, Н.C. 1977. Диагностика автотракторных двигателей. Ленинград: Колос).

Žegarac, N. 1989. Dijagnostika kliznih ležajeva u dizel motoru (in Serbian). Ph.D. thesis. Zagreb: University of Zagreb, Faculty of Mechanical Engineering and Naval Architecture.

Žegarac, N. 1993. Postupak dijagnostike ležajeva merenjem dinamičkih putanja glavnih rukavaca, kolenastog vratila (in Serbian). Serbian Patent number P-640/93.

Žegarac, N. 2020. Development of a method for determining the size of clearance in sliding bearings. Vojnotehnički glasnik/Military Technical Courier, 68(3), pp.530-553. Available at: https://doi.org/10.5937/vojtehg68-26107.

АНАЛИЗ ФАКТОРОВ ВЛИЯНИЯ, КОТОРЫЕ МОГУТ ПРИЧИНИТЬ ОШИБКИ ПРИ ПРИМЕНЕНИИ СОВРЕМЕННЫХ МЕТОДОВ

ДИАГНОСТИКИ СКОЛЬЗЯЩИХСЯ ПОДШИПНИКОВ НА МАШИНОСТРОИТЕЛЬНЫХ И ЭЛЕКТРОСТАНЦИЯ

Никола П. Жегарац

Сербская академия изобретателей и ученых,

г. Белград, Республика Сербия

РУБРИКА ГРНТИ: 55.00.00 МАШИНОСТРОЕНИЕ:

55.45.00 Судостроение,

44.00.00 ЭНЕРГЕТИКА

ВИД СТАТЬИ: оригинальная научная статья

Резюме:

Введение/цель: В статье представлено применение современных методов диагностики подшипников скольжения и анализ влияющих факторов, которые могут вызвать ошибки в применении. Представлены возможности надежного определения того, когда и где возникнет проблема, возникающая при износе подшипников скольжения при дальнейшей эксплуатации установки.

Определяется, как система будет продолжать фуункционировать с течением времени, прогнозируются причины сбоев и способы их 


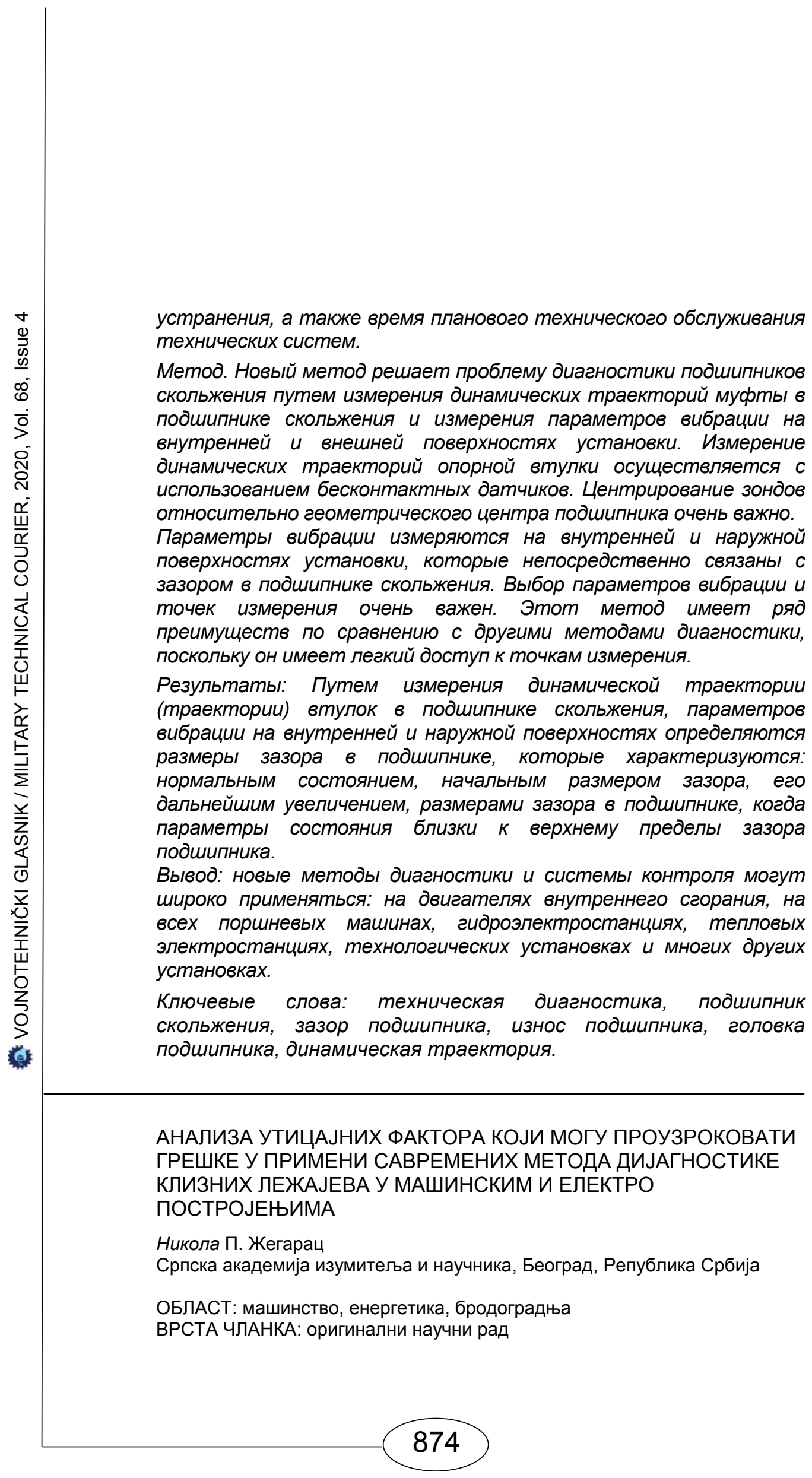




\section{Сажетак:}

Увод/циљ: У раду је дат приказ примене савремених дијагностичких метода клизних лежајева и анализа утицајних фрактора који могу проузрокавти грешке у примени. Приказане су могућности да се поуздано утврди када и где ће се појавити проблем који се јавља при трошењу клизних лежајева у даљој експлоатацији постројења. Утврђује се како ће систем наставити да фрункционише током времена, предвиђају се узроци кварова и начин њиховог отклањања, као и време за планско одржавање техничких система.

Meтоде: Нова метода решава проблем дијагностике клизних лежајева, мерењем динамичких путања рукавца у клзном лежају и мерењем вибрацијских параметара на унутрашњим и вањским површинама постројења. Мерење динамичких путања рукавца лежаја врши се помоћу бесконтактних сонди. При томе је веома важна центрација сонди у односу на геометријски центар лежаја. Врши се мерење вибрацијских параметара на унутрашњим и вањским површинама постројења који су у директној вези са зазором у клизном лежају. При томе је веома важан избор вибрацијских параметара и мерних места. Ова метода има низ предности у односу на друге дијагностичке методе, пошто је једноставан приступ мерним местима.

Резултати: Мерењем динамичке путање (трајекторије) рукаваца у клизном лежаји, вибрацијских параметара на унутрашњим и вањским површинама, утврђују се величине зазора лежаја које карактеришу: нормално стање, почетну величину зазора, његово даље повећавање, величине зазора лежаја, када су параметри стања близу горње границе дозвољеног зазора лежаја.

Закључак: Нове дијагностичке методе и мониторниг системи могу се широко применити: на моторима са унутрашњим сагоревањем, на свим клипним машинама, хидроелектранама, термоелектранама, процесним постројењима и многим другим постројењима.

Кључне речи: техничка дијагностика, клизни лежај, зазор лежаја, истрошење лежаја, рукавац лежаја, динамичка путања.

Paper received on / Дата получения работы / Датум пријема чланка: 27.06.2020. Manuscript corrections submitted on / Дата получения исправленной версии работы / Датум достављања исправки рукописа: 28.09.2020.

Paper accepted for publishing on / Дата окончательного согласования работы / Датум коначног прихватања чланка за објављивање: 30.09.2020. 
(c) 2020 The Author. Published by Vojnotehnički glasnik / Military Technical Courier (www.vtg.mod.gov.rs, втг.мо.упр.срб). This article is an open access article distributed under the terms and conditions of the Creative Commons Attribution license (http://creativecommons.org/licenses/by/3.0/rs/).

(c) 2020 Автор. Опубликовано в «Военно-технический вестник / Vojnotehnički glasnik / Military Technical Courier» (www.vtg.mod.gov.rs, втг.мо.упр.срб). Данная статья в открытом доступе и распространяется в соответствии с лицензией «Creative Commons» (http://creativecommons.org/licenses/by/3.0/rs/).

(C) 2020 Аутор. Објавио Војнотехнички гласник / Vojnotehnički glasnik / Military Technical Courier (www.vtg.mod.gov.rs, втг.мо.упр.срб). Ово је чланак отвореног приступа и дистрибуира се у складу са Creative Commons licencom (http://creativecommons.org/licenses/by/3.0/rs/). 